\title{
PROBLEMS CREATED BY STATUTORY DEFINITIONS OF THE SCOPE OF STATE COURT JURISDICTION IN SUITS AGAINST FOREIGN CORPORATIONS
}

Prior to 1945 a state court could not, under the then existing interpretation of the due process clause, exercise jurisdiction in a suit against a foreign corporation unless that corporation conducted some substantial activities within the state, such as going beyond the mere solicitation of orders. ${ }^{1}$ In that year, however, the Supreme Court, in International Shoe Co. v. Washington, ${ }^{2}$ sustained the jurisdiction of a state court over a corporation which did no more than solicit orders on a continuing basis within the state. The Court stated that the fourteenth amendment required only that there be sufficient "contacts, ties or relations" 3 between the corporation and the state so that the "traditional notions of fair play and substantial justice" 4 would not be offended by requiring the corporation to defend an action in the courts of the state. Many states did not attempt to extend the jurisdiction of their courts into the new areas opened by the International Shoe decision. ${ }^{5}$ Established rules as to the cases in which jurisdiction would be exercised were retained, thus avoiding a wave of litigation to define new standards and making the state more attractive for commercial activity by foreign corporations. ${ }^{6}$ An obvious disadvantage of this position, however, was the resulting denial of access to local courts to residents of the state wronged by activity of a corporation that did no more than solicit within the state. The burden on these persons incident to bringing suit in a distant forum ${ }^{7}$ prompted a number of states to attempt

1. See Note, 16 U. CHr. L. REv. 523, 526, (1949).

2. 326 U.S. 310 (1945).

3. $I d$. at 319 .

4. Id. at 316 .

5. See Elish v. St. Louis Sw. Ry., 305 N.Y. 267, 112 N.E.2d 842 (1953); Lutz v. Foster \& Kester Co., 367 Pa. 125, 79 A.2d 222 (1951); Note, 16 U. CHI. L. REV. 523, 533 (1949).

6. Perhaps the major reason that the courts have not taken advantage of the new jurisdiction permitted by the International Shoe decision is the reluctance with which courts throw off established doctrine. Further, in determining the relationship between the states and foreign corporations, such as the ability of the state to tax and to require corporate domestication, established tests have much value. Although the constitutional requirements differ, some courts have failed to distinguish between these areas and the jurisdictional problem. As a result, the established rules have retained their vitality. See Putnam v. Triangle Publications, Inc., 245 N.C. 432, 442, 96 S.E.2d 445,453 (1957).

7. Often the defendant foreign corporation will move to dismiss for lack of jurisdiction even though the bulk of the evidence is in the forum chosen by the plaintiff. If this motion is granted and plaintiff is forced to sue in defendant's state of incorporation, he will be presented with the expense of transporting his witnesses, and reimbursing them for loss of wages, in addition to double legal expenses. Also, the prospect of a distant trial of uncertain duration is liable to discourage voluntary attendance of witnesses who cannot be reached by subpoena. 
to define legislatively the minimum corporate activity, as outlined in International Shoe, necessary for jurisdiction in an action against a foreign corporation. 8 It is the purpose of this Comment to explore some of the problems encountered by this legislation and to suggest a possible solution of these problems.

The first problem to be considered is that of defining the grant of jurisdiction so as not to go beyond the limits permitted by due process as set by the International Shoe decision. This problem has arisen in North Carolina where recently enacted legislation ${ }^{9}$ provides that a foreign corporation will be subject to suit

"whether or not such foreign corporation is transacting or has transacted business in this state... [in causes of action arising] (1) Out of any contract made . . . or to be performed in this State; or (2) Out of any business solicited in this State . . . whether the orders . . . were accepted within or without the State; or (3) Out of the production . . . of goods . . . with the reasonable expectation that those goods are to be used or consumed in the State, and are so used or consumed . . . or (4) Out of tortious conduct in this State ...."10

In one of the first cases to be decided under the act, Erlanger Mills, Inc. v. Cohoes Fibre Mills, Inc., ${ }^{11}$ a resident plaintiff sought to invoke jurisdiction over a foreign corporation under the third subdivision. The action was for breach of a contract made and to be performed in New York, but since the goods were to be used by plaintiff in his North Carolina plant, there was no doubt that the North Carolina act, if valid, would confer jurisdiction. However, the use of the goods sold under the contract in the state was the only connection between the state and the defendant corporation. The Court of Appeals for the Fourth Circuit held that the application of the statute to invoke jurisdiction under these circumstances violated due process requirements. ${ }^{12}$

Although no court has as yet ruled on the matter, the Vermont ${ }^{13}$ and the recently enacted Minnesota ${ }^{14}$ statutes apparently are open to attack on the same grounds. These statutes provide:

8. The following states constitute this group: Maryland, Mp. ANN. CODE art. 23, $\$ \$ 92,96(d)$ (1957); Minnesota, MINN. STAT. ANN. \$\$ 303.13 (1), (3) (1945); North Carolina, N.C. GEN. STAT. \$ 55-145 (Supp. 1957); Tennessee, TENN. CoDE ANN. \$\$ 20-220, 48-910 (Williams 1955); Vermont, Vt. REV. STAr. \$1562 (1947); West Virginia, W. VA. CODE ANN. $\$ 3083$ (Supp. 1957); and, to a limited extent, Florida, Fra. Stat. AnN. $\$ 47.16$ (Supp. 1957).

9. N.C. GEN. StAT. \$ 55-145 (Supp. 1957).

10. Ibid.

11. 239 F.2d 502 (4th Cir. 1956).

12. The North Carolina Supreme Court held the same subsection unconstitutional as applied in an action for libel against a foreign corporation which sold magazines in another state to be retailed in North Carolina. Putnam v. Triangle Publications, Inc., 245 N.C. 432,96 S.E.2d 445 (1957).

13. VT. REV. STAT. § 1562 (1947).

14. Minn. Stat. Ann. $\S 303.13$ (1), (3) (1945). 
"[I]f a foreign corporation makes a contract with a resident of [the state] . . . to be performed in whole or in part in [the state] ... or . . commits a tort in whole or in part in [the state]... against a resident of [the state] . . . such acts shall be deemed 'doing business' . . . [and shall authorize service of process on the Secretary of State] in any action or proceedings . . . arising from or growing out of such contract or tort." 15

It would seem that this provision allows jurisdiction over foreign corporations in situations where the only contact between the foreign corporation and the state is a single act or sporadic activity. Exercise of jurisdiction under such circumstances is not always in violation of the Constitution, ${ }^{16}$ but there are situations in which single contacts cannot serve as a basis of state jurisdiction. ${ }^{17}$ The new West Virginia act ${ }^{18}$ follows the Vermont law verbatim except that the requirement that the suit be one ". . . arising . . . out of such contract or tort" ${ }^{10}$ is omitted. Thus the West Virginia act would seem to allow jurisdiction over foreign corporations in even more extreme cases than would the Vermont act. For instance, in its only contact with West Virginia a New York corporation arranges to sell goods to a West Virginia merchant to be delivered to the latter at his local warehouse. The West Virginia act would apparently allow the New York corporation to be made amenable to suit by any resident of the state who felt he had a cause of action against the corporation. Minimal contacts such as this as grounds for exercising jurisdiction might not violate due process when the suit is in some manner connected with the corporate activities within the state, but should the suit be totally unconnected with these activities, it is doubtful that the Federal Consitution would allow jurisdiction. ${ }^{20}$

A second problem presented by these statutes may be illustrated by reference to the difficulty which has arisen under provisions that a foreign corporation doing business in the state shall be liable to suit for "any acts or omissions" of the foreign corporation in the state.21 In the recent case of

15. Ibid.; VT. Rev. STAT. \$ 1562 (1947).

16. See Smyth v. Twin State Improvement Co., 116 Vt. 569, 80 A.2d 664 (1951).

17. McGee v. International Life Ins. Co., 355 U.S. 220 (1957) ; Erlanger Mills, Inc. v. Cohoes Fibre Mills, Inc., 239 F.2d 502 (4th Cir. 1956).

18. W. VA. Code ANn. $\$ 3083$ (Supp. 1957).

19. VT. REv. STAT. $\S 1562$ (1947).

20 See Note, 104 U. PA. L. REv. 381, 387, 397 (1955). Generally, these statutes provide for jurisdiction only in actions involving a resident of the state. MD. ANN. CODE art. 23, \$92(d) (1957); VT. REv. STAT. \$1562 (1947). Thus nonresidents injured in the state would be precluded from invoking these statutes unless the matter in dispute also involved a local citizen. This result often may leave the nonresident at a disadvantage. However, since the term "resident" need not be interpreted to mean citizen, there would most likely be no problem under the privileges and immunities clause of the Federation Constitution. Cf. Douglas v. New York, N.H.\&H. R.R., 279 U.S. 377 (1929).

21. E.g., Colo. Revi Stat. Ann. \$31-10-2(6) (Supp. 1957); Ind. Ann. Stat. § 25-316 (Burns 1948); MD. ANN. CoDE, art. 23, § 92 (d) (1957). 
Florio v. Powder Power Tool Corp., ${ }^{22}$ a foreign corporation was held to be amenable to suit in Pennsylvania under such a statute. Although the suit arose out of an injury occurring in Pennsylvania, the injury was caused by the faulty operation of a tool negligently manufactured in Oregon. The court held that the "act" referred to in the statute was the injury to plaintiff and that therefore the statute permitted the court to exercise jurisdiction. ${ }^{23}$ Some courts in similar cases apparently construe "act" to mean the negligent manufacture of the goods, thus precluding jurisdiction. ${ }^{24}$ The wide variety of factual situations which may arise with regard to the local contacts of foreign corporations requires that broad and ambiguous terms such as "act" be used to define the scope of jurisdiction. Thus uncertainty and arbitrary decisions such as those illustrated above are the inevitable result of any statute which attempts a mechanical definition of the type of cases in this area over which state courts have jurisdiction.

One possible solution to the problems raised by the legislation attempting specific definition is exemplified by recent developments in Pennsylvania. That state's 1957 Business Corporation Act ${ }^{25}$ repealed the definition of the types of corporate activities which would bring a foreign corporation under the jurisdiction of its courts, and returned Pennsylvania to a position of exercising jurisdiction over corporations "doing business" in the state. ${ }^{26}$ Prior to the enactment of the repealed definition, Pennsylvania courts applied this same provision in such a way as to permit jurisdiction only in cases where corporate activity was considerably more than that required by the International Shoe case. ${ }^{27}$ It may develop that Pennsylvania courts will return to this prior interpretation. However, it is arguable that the repeal of the specific tests for jurisdiction represents a realization by the legislature that mechanical tests to outline maximum state jurisdiction over foreign corporations are not feasible, ${ }^{28}$ and not an

22. 248 F.2d 367 (3d Cir. 1957).

23. $I d$. at 374 .

24. Johns v. Bay State Abrasive Products Co., 89 F. Supp. 654 (D. Md. 1950).

25. PA. Star. ANN. tit. 15, \$2852-1011 (Purdon Supp. 1957).

26. The repealed portion of the statute defined doing business as ". . the doing of a series of similar acts for the purpose of thereby realizing benefits or otherwise accomplishing an object. . ." Act of September 26, 1951, P.L. 1475, § 22, as amended, Act of August 19, 1953, P.L. 1119, $\S 10$, repealed by PA. STAr. ANN. tit. 15, $2852-$ 1011 (Purdon Supp. 1957).

27. Lutz v. Foster \& Kester Co., 367 Pa. 125, 79 A.2d 222 (1951); New v. Robinson-Houchin Optical Co, 357 Pa. 47, 53 A.2d 79 (1947).

28. Although the legislative history is unclear, dictum in lower state courts may have motivated the repeal. See Cieri v. Dante, 54 Lackawanna Jurist 33, 36 (Pa. C.P. 1952). Or the results which the statute was producing in federal courts might have been unpopular in the legislature. E.g., Solt v. Interstate Folding Box Co., $133 \mathrm{~F}$. Supp. 7 (E.D. Pa. 1955) ; Jenkins v. Dell Publishing Co., 130 F. Supp. 104 (W.D. $\mathrm{Pa}$. 1955). Or it may indicate a legislative preference for the solicitation plus test applied by the courts before the passage of the act defining doing business. Lutz $\mathrm{v}$. Foster \& Kester Co., $367 \mathrm{~Pa} .125,79$ A.2d 222 (1951). It is not unreasonable to conclude, however, that the repeal indicates a legislative dislike for definitive tests in this area. The original draft of Senate Bill 573 (later codified into PA. STAT. ANN. tit. 15, $\$ 2852-1011$ (Purdon Supp. 1957)) included a list of specific activities which were not to constitute doing business. The ultimate striking of this list perhaps indicates that the legislature did not wish to enact inflexible standards concerning what is to constitute doing business. 
expression of a desire to return to prior standards. ${ }^{29}$ Pennsylvania courts under this approach are free to adopt the International Shoe test as the definition of "doing business." 30 Some states operating under "doing business"-type statutes have adopted this definition. ${ }^{31}$ The Pennsylvania legislature's approach is not the best answer to the problem, however, as it makes the outcome of future litigation uncertain, and does not insure that the courts will adopt the standard which the legislators intended.

Because due process questions can be decided only by an analysis of the factual situation of each case, it seems impossible to devise a statute which expands state jurisdiction over foreign corporations without creating considerable difficulties. The statutes presently in force do prompt courts to take full advantage of the permissible scope of state jurisdiction, but although they purport to provide specific tests, no more certainty is achieved than is possible under the current rationale of due process, and often considerable uncertainty arises over the interpretation of broad terms. Therefore, if it is the purpose of the legislature to make full use of the jurisdiction permitted by the International Shoe decision, it would seem desirable to employ a statute which directs the courts to hold a foreign corporation amenable to suit in every case except those where the due process clause of the Federal Constitution interferes.

29. This would be in keeping with the trend discernible in other states. See McGee v. International Life Ins. Co., 355 U.S. 220, 222-23 (1957).

30. See Note, 16 U. CHI. L. Rev. 523, 526 (1949).

31. See Duraladd Products Co. v. Superior Court, 134 Cal. App. 2d 226, 285 P. 2d 699 (1955); Martin Bros. Elec. Co. v. Superior Court, 121 Cal. App. 2d. 790, 264 P. 2d 183 (1953); A. \& M. Trading Corp. v. Pennsylvania R.R., 13 N.J. 516, 100 A.2d 513 (1953); Miklos v. Liberty Coach Co., 138 A.2d 762 (N.J. App. Div. 1958). 